\title{
DIE ONTSTAAN EN ONTWIKKELING VAN DIE PAN-AFRIKANISME EN DIE IMPLIKASIES DAARVAN
}

Afrika in die Wêreldpolitiek.

Dit was nie voor 1880 dat tropiese Afrika, dit is die grootste gedeelte van Wes-, Oos- en Midde-Afrika, deur ontdekkingsreisigers, handelaars en sendelinge tot so 'n mate ontsluit is, dat dit in die vaarwater van die wêreldpolitiek geraak het nie. Lank voor hierdie tyd is natuurlik steunpunte aan die Wes-, Suid- en Ooskus deur die Porlugese en later die Nederlanders en Engelse heset ter wille van of die slawehandel en/of as steunpunte op die lang handelsweg na die ryke Ooste.

Met die uitsondering van die uiterste Suidpunt, waar'n Blanke Nedersetting ontstaan en na die linneland uitgebrei het (in 'n gelied nog nie betrek deur die Ban. toe, die woongebied van Hottentotte en Boesmans), was hierdie vroeë Europese steunpunte beperk tot die kusgebiede en was daar weinig prikkel vir die destydse seehandelsvolke om na die moeilik-toeganklike hinneland in te dring.

In hierdie steunpunte aan die kus het 'n hetreklik geringe aantal wit amptenare, kooplui en sendelinge gewoon, wie se getalle jaar na jaar moes aangevul word as gevolg van die verwoesting deur koors en ander tropiese siektes. Hulle het hulle by hulle onmiddellike omgewing en werksaamhede bepaal en het omtrent nie in aanraking gekom met die inboorlinge van die binneland nie.
Tropiese Afrika het gebly 'n wit vlek op die landkaart, die jagveld van Arabiese en ander slawehandelaars wat verwoesting onder die inboorlinge gesaai het, 'n wêreld in die greep van stamvetes, tropiese siektes, onkunde, ekonomiese stagnasie gehaseer op 'n blote lestaansekonomie.

Eers na 1890 is Afrika in sy geheel, minstens op die landkaart, in kolonies verdeel, en in hierdie proses is daar uiters willekeurig te werk gegaan. Dikwels is gewoonweg lengte- en breedtegrade as grense bepaal sonder om te let op die hevolkingsstruktuur en stammesamestelling, iets wat later en selfs tot in ons tyd baie moeilikheid veroorsaak hel.

Van hierdie tyd af het die betrokke koloniale magte hulle gesag geleidelik oor die hinneland, wat hulle onderskeidelik toegeval het tydens die verdeling, uitgebrei. Dat daar ' $n$ afkeer was teen die blanke gesagindringing, kan nie betwyfel word nie, maar die inboorlinge met hulle versplitterende stamorganisasies, het nêrens 'n staatkundige saamhorigheid vertoon wat opgewasse was teen die oorwig van die verteenwoordigers van die koloniale moond. hede nie. Die Neger- en Bantoe-inboorlinge, hewus van hulle heskawingsagterstand, ge. meet met die van hulle nuwe here, hevry van die skrik van die slawejagters en van die verwoesting van die onderlinge stamoorloë, het geleidelik die voordele van 'n 
tot dan toe ongekende bestaansveiligheid begin besef en hulle daarom met minder innerlike verset in die toestand van onderhorigheid geskik as wat mens sou verwag.

Daarby moet onthou word dat oor die algemeen die houding van die koloniale heersers van die 19e eeu en van hulle verteenwoordigers in Afrika, op weinig uitsondering na, veel mensliker was as die van die mense van vroeëre dae. Dit het die proses van aanpassing makliker gemaak.

Niemand het destyds egter daaraan gedink om selfs die inboorling-elite te behandel en te beskou as gelykes nie, en nog minder om hulle 'n aandeel in die regering of administrasie te gee nie. Die verste (heeltemal in die algemeen gesproke) wat die Franse en Portugese wou gaan was om die inboorlinge wat die Europese lewenswyse en kultuur aanvaar het as swart Franse of Portugese te beskou en om aan hierdie ,evolués" die regte en voorregte toe te ken wat aan die Franse en Portugese burger onderskeidelik toegekom het. Hulle getalle was gering en het so gebly. Wie Britte diarenteen het in hullc tropiese holonies nie verder grgaan nie as om volgens lord Lugard se resep van Indirect Rule, van die stamhoofde gebruik te maak as skakels tussen die administrasie en die groo1 massa vim die bevolking.

Hierdie houding en praktyk het berus op die destydse algemene opvatting dat die Neg:rs en Bantoe kragtens hulle rasseaard rie uit eie krag in staat is om 'n geordende staat in te rig of staande te hou nie. Die vaste oortuiging was daar dat hierdie inboorlinge vir altyd, of vir ten minste 'n onafsienbare tyd lank as politiek onmondiges onder die voogdy van vreem- de heessers sou moet staan.

$\mathrm{Na}$ gelang die Europese gesag gevestig geraak het is 'n begin gemaak met die hestryding van die verwoestende tropiese siektes van mens en dier (veral malaria, slatpsiekte en ngana) en van die verwoesting van die bodem deur gronderosie.

So is daar dan by die einde van die vredesera teen 1914 heelwat bereik. Die veedsame lewenshestaan is verseker deur die uitskakeling van die stamoorloë en die bedrywighede van die slawejagters; '" begin is gemaak met die verhoging van die lewenspeil en met die bestryding van tropiese siektes. In vergelyking met die vioeëre toestande het Blanke-beheer dus baie seëninge meegebring, maar dit het ook vir baie van die snel-vermeerderende hevolking heteken die einde van 'n luilekker lewe in die son. Dit het meegebring die onbekende ervaring van inspannende arbeid om te kan bestaan. Fn dit, meer as iets anders, het waarskynlik aan die wortel gelê van die voorasnog liedekte, maar nietemin smeulende afkeer van die blanke heerskappy.

Die uitwerking van die twee wêreldoorlö̈.

In hierdie toestande het die tweede Wêreldoorloë 'n grondlige en verreikende verandering gebring. Fk sal probeer om die belangrike faktore van die proses te ontleed en saam te vat.

(a) Die Ferste Wêreldoorlog het die magsposisie in die wêreld van die Europese koloniale moondhede tot in sy fondamente geskud en die Tweede Wêreldoorlog het die voltooiing van die proses van aftakeling meegelıring. In die Tweede Wêreldoorlog het die Geel en Swart volke van die wêreld met verbasing aanskou hoedat 
'n Asiatiese Moondheid groot oorwinnings behaal oor hulle blanke teenstanders op see en in Maleia en Indonesië. En hoewel hicrdie oorwinnings weer uilgewis is, was die invloed daarvan op die gemoed van die nie-hlankes onberekenhaar groot. Hulle sou ook weldra die getuie word van die terugtog uil die Ooste van die Nederlanders, die Franse en die Engelse onder die druk en/of met die goedkeuring en aanmoediging van veral Amerika, wat ontpop het as die voorvegter van die antikolonialisme, waarop ek later sal terugkom. Die vrywording van Indonesië, Indië, Pakistan, Ceylon, Birma en Maleia het oral in Afrika, en veral op die intelligentsia grool indruk gemaak.

\section{(1.) Die Nie-blankes in Afrika word in oorloë betrek.}

In beide oorlö̈ het die Bondgenote teen Duitsland hulle mannekrag aangevul met Indiese en Afrikaanse inhoorlingsoldate. Tydens die Tweede Wêreldoorlog bet die Franse en die Engelse meer as 400,0001 swart soldate in Afrika gewerf en gebruik. llierdie manne uit Njassaland, NoordRhodesië, Tanganjika, Kenia, Oeganda. Wes- en Ekwatoriale Afrika is gebruik in Ahessinië, Somaliland, Noord-Afrika, en 'n ansienlike aantal oorsee in Madagaskar, Mauritius, Palestina, Aden, Ceylon en Birma. Hulle het ver gereis, haie ervaar, gesien en geleer. IJulle het die ,stamoorloë" van die blankes van redelik naby heskou en was toeganklik vir die propagandakrete van die een deel van die blan. kes teen die ander deel. Hulle het gehoor hoe daardie blankes uitgemaak is as onderdrukkers, moordenaars, en as alles wat dierlik en onmenslik is. Hulle het ge- leer dat hulle heersers mense is van gelyke beweging as hulle, en geen onaantasbare halfgode nie. Hulle ontsag vir die blanke is grondig ondermyn indien nie heellemal vernietig nic.

\section{(c) Die anti-kolonialisme.}

Daarby hel gekom die verbasende reaksie in Europa self teen die rasseopvaltinge van die Nasionaal-sosialisme en die Fasjisme. 'n Diep skuldgevoel het by dic Europa-mens ontstaan in verband met sy koloniale bedrywighede, wat huite alle verhouding gestaan het tot die werklikheid. en die twyfel en onsekerheid wat deur hierdie skuldgevoel gewek is het die koloniale moondhede uiters ontvanklik en kweshaar gemaak vir die propaganda van die anti-kolonialisme. Dit maak dit notlig on hierdie politieke denkrigting nader te ontleed. Hoewel beide die V.S.A. en Rusland meegedoen het aan die Nuwe Imperialisme van die $19 \mathrm{e}$ eeu, het hierdie twee lande tydens en veral na die 'Tweede Wê. reldoorlog hulle laat ken as die grool voorvegters van die anti-kolonialisme.

\section{(i) Die V.S.A}

Die Amerikaners het nooit vergeet dat hulle cenmaal self 'n kolonie was en dat hulle hul onafhanklikheid te danke het aan 'n gewelddadige stryd teen die moederland nie. Maar in sy diepste grond is die alkeer van die Amerikaners van 'n heersersposisie met militêre en politieke mirldele sonder die toestemming van die geregeerdes versterk deur 'n eerlike Christelik-Humanitêre denke. Dat hulle anti-kolonialisme egter nie heeltemal altruïsties was en is nie word bewys deur hulle "Dollar-imperialisme" in Suid-Amerika vanaf die helfte 
van die $19 \mathrm{e}$ eeu en deur die duidelike aanduidings in ons tyd dat hulle wel bereid is om aan die volke onder hulle invloed politieke onafhanklikheid na buite te laat, maar van hulle ook verwag om in hulle politieke struktuur en doelstellings hulle net soseer na die Amerikaanse wense te rig as wat hulle van die ekonomiese hulp en beleggingsgelde van laasgenoemde afhanklik is. Die na-oorlogse prekêre politieke ewewig tussen die kapitalistiese Weste en die Kommunistiese Ooste, en die magsworsteling in die koue oorlog tussen die twee, verhewig deur die ontwikkeling van kernwapens ook deur laasgenoemdes, het die mededinging om die steun van die politiek nog ongekompromitteerde Asiatiese en Afrikaanse hordes verskerp, en 'n verhewigende en versnellende invloed op die anti-kolonialistiese beleid van die V.S.A. uitgeoefen.

Die politieke en ekonomiese afhanklikheid van die Westerse wêreld van Amerika het aan laasgenoemde die mag verskaf om 'n ontsettende druk op sy bondgenote uit te oefen om sy eie beskouing, dus ook t.o.v. die koloniale gebiede, te aanvaar en om alles in die werk te stel om selfregering en onafhanklikheid binne die kortste tydsbestek aan die onderhorige gebiede toe te ken, sonder om selfs rekening te hou met die belangrike vraag of die betrokke volke in staat is om die verantwoordelikheid te dra sonder groot skade vir hulle en vir die wêreldvrede.

Wat die Weste betref, was die eerste stap wat aangetoon het hoe die wind gaan waai, die Atlantic Charter wat deur Roosevelt en Churchill in Augustus 1941 op see uitgevaardig is. Hierdie Charter het o.a. die herstel van soewereine regte aan alle volke wat daarvan beroof is belowe sowel as die reg van alle volke om hulle eie regeringsvorms te kies.

Weliswaar het Churchill in Septemher 1911 in die /louse of Commons verklaar dat die hepaling hedoel was vir Europese volke wat hulle vryheid verloor het en nie vir ,the regions and peoples which owe allegiance to the British Crown"; maar die verslag van "The Committe on Africa, the war and Peace Aims" wat deur die geld van 'n Amerikaanse stigting, die Phelps-Stokes Fund, moontlik gemaak is en in 1942 onder die titel The Allantic Charter and Africa from an American standpoint verskyn het, skilder 'n heelwat ander prentjie. En sinds die tyd het die Amerikaanse houding in hierdie verhand steeds duideliker geword.

(ii) Rusland wat beide onder die Tsaristiese bewind en onder die Kommunisme sy grense uitgebrei het oor Asiatiese volke vanaf die Oeralgebergte lot aan die kuste van die Stille Oseaan, het paradok. saal genoeg hierdie bedrywigheid as normale uitbreiding van die Russiese Ryk en nie as kolonialisme beskou nie, en daarom kon die Kommunistiese leiers vanaf Stalin tot op Kroestjof hulle op die mees siniese wyse voordoen as voorvegters van die anti-kolonialisme. In die grond van die saak het die anti-kolonialisme dus weinig meer geword as 'n propagandawapen van die magspolitiek, en in die jongste tyd hel Afrika hiervan die brandpunt geword. Hier het dit aan die leiers van die Afrika. niste die geleentheid gebied om altyd groter en meer drastiese eise te stel in die sekere wete dat daar hard geywer word om hulle guns.

Rusland het die voordeel dat die ont. 
kenning van die reg op privaatbesit en die aanvaarding van 'n eenparty-diktatuur aansluit by die tradisies van sowel die Asiatiese as die Afrikavolke. En dit juis makk die Russe en Chinese in Asië en Afrika sulke gevaarlike mededingers, en dit weer spoor dic Amerikaners aan om steeds groter druk op hulle bondgenote uit te oefen om die ,hevryding" van die Afrika-ge. meenskap selfs op onoordeelkundige wyse le verhaas.

Swart Nasionalisme of Afrikanisme.

Die wêreld-politieke faktore hierbo bespreek staan in die nouste verband met die ontstellende vinnige groei van die Swart Nasionalisme of Afrikanisme, maar die ontstaan daarvan is bepaal deur beide binnelandse en buitelandse faktore. Die Pan-Afrikanisme het sy wortels nie in Afrika self nie, maar by Neger-afstammelinge buite Afrika. Die idee het sy oorsprong by die Wes-Indiese regsgeleerde, Henry Sylvester Williams, wat so vroeg as 1900 'n Pan-Afrikaanse Konferensie in J.onden byeengeroep het om te protesteer teen die ,aggressiewe optrede van Wit Koloniseerders" in Afrika. Sylvester Williams is egter 'n paar jaar later oorlede. Wat hy begin het is met groot doelgerigtheid voortgeset deur dr. William du Bois, 'n Amerikaner van Neger-afstamming en leidende figuur o.a. in die Amerikaanse "National Association for the Advancement of Coloured People" (NAACP) gestig in 1910. Die program wat hy omstreeks 1905 in 'n manifes (An address to the Comntry) vir die Negers in Amerika opgeslel het is insiggewend:

,First. We would vote... we want full manhood suffrage, and we want it now, henceforth and forever.
Second. We want discrimination in public accommodation to cease...

Third. We claim the right of free men to walk, talk and to be with them that wish to be with us."

Wat die Afrikane in Afrika self betref, sou later bykom die eis om selfbeskikkingsreg en politieke onafhanklikheid.

Tussen 1919 (tydens die vredesonderhandelinge in Versailles) en 1945 het dr. Du Bois meegewerk en deel gehad aan vyf Pan-Afrikaanse Kongresse. Hulle is hoofsaaklik bygewoon deur 'n klein groepie van die intellektuele elite uit die V.S.A., die Wes-Indiese eilande en die Verenigde Koninkryk. Die vyfde kongres in 1945 in Londen het egter reeds meer in die teken van komende dinge gestaan.

„Representation was drawn from the ranks of political, trade union and farmers' movements... a new militant leadership was reflected, closely linked with the popular movements in the home lands" (George Padmore: Pan-Africanism or Communism? p. 161). Selfs die name van die ,internasionale sekretariaat" wat die voorhereidende werk gedoen het, is veelseggend: Dr. Peter Milliard van BritsGuiana, T.R. Makonnen, Brits-Guiana, George Padmore, Wes-Indië, Kwame Nkrumah, Wes-Afrika, Peter Abrahams, Suid-Afrika en Jomo Kenyatta, Oos-Afrika.

Hierdie vyfde Pan-Afrikaanse Kongres het die koloniale magte, Brits, Frans, Belgies en andere in Wes-Afrika, daarvan beskuldig dat hulle bestuur meegebring het ,agteruitgang instede van vooruitgang" as gevolg van uitbuiting op politieke, ekonomiese en sosiale gebied. Dit het die georganiscerde Christendom uitdruklik vereenselwig met die ,politieke en ekonomiese 
uithuiting" en hom eenparig vereenselwig met die sicnwyse van die Wes-Afrikaanse afvaardiging dat slegs algehele onafhanklikheid van Wes-Afrika die probleme sou oplos. Die soeklig is ook gerig op die rassevraagstukke in die Unie, Sentraal- en (Oos-Afrika, en 'i heroep op die Arbeidersparty on Vakhondwese van Groot-Brittanje gedocn om die Afrikane die maksimum luulp te hied in hulle stryd teen luulle „Herrenvolk oppressors". Daarmee is die program van die Pan-Afrikanistiese aksie in groot lyne uilgestippel. Die heweging is bitter vyandig teen enige vorm van kolonialisme, teen Blanke oppergesag en alle vorme van rasse-diskriminasie. Dit eis volle onafhanklikheid vir alle Afrika-state op die grondelag van regering deur die meerderheid gehaseer op die gedagte van één man, één sicm. Daarloy vind die aksie plaas teen die allergunsigste agtergrond van wêreldpolitieke verhoudinge, veral soos dit voortgekom het uit die koue oorlog.

Dit word derhalwe nodig om noukeuriger in te gaan op die inslag van die PanAfrikanisme in Afrika self, en om die ontstaan en die psigologiese en politieke instelling van die draers daarvan in Afrika nader te ontleed.

\section{Dic ,Intellektuele Elite”.}

Die ekonomiese ophloei, en gepaard daarmee, die versnelde ontginning van dic hulplirome van Afrika na die Eerste, maar veral na die Tweede Wêreldoorlog, het 'n steeds groter aantal Nie-hankes in aanraking met die Westerse lewenswyse en heskawing gebring. Oral is meer aandag geskenk, veral deur die sendelinge, met die steun van die verskillende owerhede, aan die onderwys, en 'n klein maar tog steeds aangroeiende aantal swart leerlinge het tot by die Middelbare onderwys deurgedring. Die na-oorlogse ekonomiese opbloei het in verskeie dele en veral in WesAfrika die ontluiking van 'n hetreklik welvarende middelstand veroorsaak en hierclie mense was in staat om, met die hulp van allerlei instansies, hulle seuns te help om oorsee te gaan na Wes-Europese, Amcrikaanse en Russiese tegniese skole en/ol universiteite. In die loop van die jare het hicrdie stroom van swart hesoekers aan die buiteland steeds aangegroei en die uitwerking daarvan op hulle, en deur hulle op die massas in hulle tuislande, kan nou. liks oorskat word.

Micrdie weetgierige jong hesoekers aan Amerika en Europa, insluitende Rusland, het gemerk dat hulle swart vel wel af en toe tot minder aangename ervaringe aanleiding gegee het, maar dat oor die algemeen daar nie teen hulle gediskrimineer word nie. Hulle het sy aan sy met blankes op die universiteitshanke gesit of saam in die fabrieke gewerk. Hulle het die geweldige tegniese prestasies bewonder en liaie van hulle het daarvan een en ander geleer. Hulle het die hetreklik hö̈ lewenspeil van die arbcidende klasse gesien en dit met dic in hulle tuislande vergelyk. Hulle het vertroud geraak met die jdeale van die Jiberalisme en met sy leer van personnlike vryhıid, maar ook met dic Sosialisme wat daarin geslaag het om deur organisasie en werkstakings die oorwig van die kapitalistiese werkgewers te verbreek. Hulle het die leerstellinge vall die demokrasie, wat aan elke staatshurger, afgesien van sy herkoms, plek in die samclewing, of prestasie dicselfde regte tocken, ingedrink. Hulle het geleer dat in hierdie stelsel slegs die ge- 
talle-meerderheid die deurslag gee, want die stemme word getel en nie geweeg nie. Hulle het geleer dat voortaan geen bevoorregte klasse (soos die Blankes in hulle tuis. lande) meer aanspraak kan maak op voorrang as gevolg van prestasies van die ver. lede of die hede nie. Hulle het geleer hoe die verfynde propagandategniek in staat was om binne korte tyd die massas vatbaar te maak vir die uitvoering van die wil van leiers en agitators.

In 'n insiggewende artikel (The Intellectuals in the Political Development of the New States, World Politics, Vol. XII, No. 3, April 1960) skets Edward Shills die rol van sekondêre skole en universiteite in hier. die verband as volg:

„Formally, the student movements in the colonial countries began their careers only in the 1920's, but long hefore that the secondary schools, colleges and universities had been a source of personnel for the more ebullient and agressive nationalistic movements. Since the begimning of the present century, students have been in a state of turbulence. This turbulence flow. ed more and more into politics, until the students became vital foci of the national independence movements. The secondary schools, colleges, and universities attended hy the students of underdeveloped countries hecame academies of national revolution. It was not the intention of the administralors and teachers that they should become such; rather, the contrary. Nonetheless they did, both in their own countries and in the metropolitan centres of London and P'aris, where many of the most important architects of independence were trained, and where they found the intellectual resonance and moral support which sustain- ed them in lean years.

„The London School of Economics in particular has probably contributed much more to the excitation of nationalistic sentiment than any other educational institution in the world. At the School of Economics, the late Professor Harold Laski did more than any other single individual to hearten the colonial students and to make them feel that the great weight of liberal Western learning supported their political enthusiasm.

"However, it was not only in the universities of London and Paris, but in shabby clubs and cafés, cheap hotels and restaurants, dingy rooming houses and the tiny cluttered offices of their nationalist organizations that the colonial students were educated in nationalism, acquired some degree of national consciousness, and came to feel how retrograde their own countries were and what they might be if only they hecame their own masters and modernized themselves. Personalities like Mr. Krishna Menin, Dr. Nkrumah and Dr. Banda, were themselves formed in these milieux, and in turn formed many of those who were to play an active part in the movement in their own countries."

\section{Toewyding van die Intellektueles aan die} P'olitiek.

Opvallend van die intellektuele bolaag is hulle loewyding aan die politiek. Tot 'n mate hang dit saam met die aard van hulle opleiding, maar die vraagstuk van werkverkryging in hulle tuislande het hierin 'n helangrike rol gespeel. Toegang tot werkgeleentheid was in hoofsaak beperk tot die opvoedkundige en mediese beroepe. Die staatsdiens was oor die algemeen vir 
hulle gesluit, terwyl die algemene toestande, sowel as hulle agtergrond, gebrek aan tegniese kennis e.d.m. hulle weinig moontlikhede gebied het om 'n plek te vind in die hoëre range van die handel, die nywer. heid en die ingenieurswese. Gegradueerdes was dikwels verplig om werk te aanvaar wat hulle as onlonend en benede hulle waardigheid beskou het. Hulle uitwendige cn ö̈nskynlike onderwerping aan hierdie toestande het 'n diepliggende en steeds aangrociende geval van vyandigheid hedek.

Hierdie mense het die kortpad na aansien en welvaart gesien in die politiek. Die woorde wat dr. Kwame Nkrumah laat aan. bring het op die voetstuk van sy trotse standbeeld voor die administratiewe geboue in Accra: Soek cers die koninkryk van die politick on alle under dinge sal jou toegewerp word, is 'n presiese weergawe van die opvattinge en geestesgesteldheid van die meeste intellektuele leiers van die Niehlankes in Afrika.

\section{Pan-Afrikanisme en Nasionalisme.}

Uit dic voorgaande kort ontleding van die ontstaan en aard van die draers van die Pan- $\Lambda$ frikaanse gedagte, is dit duidelik dat die Pan-Afrikanisme nie verwar moet word met Nasionalisme in die gangbare belekenis van dic woord nie. Swart Afrika behoort demografies tot dic bontste gebiede van die wêreld. $0 \mathrm{~m}$ één voorbeeld te neem : die 12 miljoen inboorlinge van die vroeëre Belgiese Kongo val uiteen in ongeveer 120 kleinere en grotere, dikwels onderling vyandige stamme, met eweveel verskillende tale. In die meeste ander nuwe onafhanklike state, sowel as in ons eie land, word in mindere of meerdere mate dieselfde verskynsel aangetref. Die Pan-Afrikanisme is dus geen staats- of groepspatriotisme nie, maar eerder die ontwaking by 'n betrek. like dun, onder Europese invloed ontwikkelde bolaag, van 'n Afrika-bewussyn wat meer rassies en sosiaal as nasionaal is. Die saambindende en rigtinggewende faktor daarin is die haat teenoor die Blankes, wat op sy beurt nie in die eerste plek 'n reaksie is (soos so dikwels voorgewend) teen onderdrukking nie, maar wel teen rasse. diskriminasie, wat aangevoel word as 'n klad op hulle waarde as mense, en daarom as 'n dodelike en onvergeeflike hclediging. Dis om hierdie rede dat selfs die belejd van "partnership" vir die Pan-Afrikanis op die duur onaanneemlik is. Ook daarin voel die Swartman hom steeds bedreig deur die werklike of vermeende meerderwaardig. heid, die grotere bedrewenheid en ,knowhow" van die Blanke. Daarom is daar by hom 'n onkeerhare drang tot Swart domi. nasie, waarin die Blankes hoogstens 'n ondergeskikte plek mag inneem om hulle bedrewenheid onder en ten bate van die nuwc Swart heersersklas te beoefen.

Dicselfde psigologiese agtergrond ver. klaar die verbete vyandigheid van die nuwe intellektuele leiers teen die tradisionclo stamowerhede, wat vir hulle die toonbeelde is van gelokaliseerde magsuitoefening en van onwilligheid om die Witman of uit te dryf of dienshaar te maak aan Swart dominasie.

Die Pan-Afrikanistiese beweging is grootliks bevorder deur die opkoms van bekwame politieke leiers soos Kwame Nkrumah van Ghana, Azikiwe van Nigerië, Leopold Senghor van Senegal, Kenyatta en Tom Mboya van Kenia en Julius Byerere van Tanganjika. Die meeste van hulle ken mekaar en het reeds in Europa met mekaar 
en met ras- en geesgenote uit die Verenig. de Koninkryk, Frankryk, en Wes-Indië saamgewerk. Hulle staan in noue voeling mel die groot groepe liberaliste en ander linksgesindes in Europa en Amerika, en het die voordeel dat hulle tuis is in twee wêrelde, die wêrelıl van die Afrikaanse Bumdu van vooroners-verering, rituele danse en die toordokter en die wêreld van parlementêre dehat en magsworsteling volgens Europese patroon. Die fenomenale proses van verstedeliking van die Negers en die Bantor, veral na 1939, het hulle politieke strewe vergemaklik en in die hand gewerk. Die legniek van heïnvloeding van dic massas wat hulle in Amerika, Europa en Rusland aangeleer het kon in die stede maklik loegepas word deur te wys op die teëstelling tussen die besittende Blankes en die nie-liesillende Swarles en die verskil toe te skrywo hloot an die besit van die politieke mag. Dit was, en is, nie te moeilik om dic saamgedronge en deels ontstamle massas, wat dikwels in bekla. enswardige loestande moes lewe, toestande wat die gevolg was van die nywerheidsomwenteling, aan te hits tot sahotasie deur werkstaking, tot onluste en opstootjies en selfs tot dic vernicliging van wat vir hulle eie l,eswil daargestel is, soos skole, kerke, klinieke, beesdippe e.d.m. Daarby is en word op grool skaal gebruik gemaak van intimidasie van die ordelike elemente deur leeglêers en tsolsis, die ,skoktroepe" van die beweging. Hierdie metode om die massas in te span is gedurende die Mau Mau. mluste op grool en weersinwekkende skaal in Kenia gebruik, en in sy voorsittersrede voor die United Federal Parly se kongres op 20/2/01 gee sir Roy Welensky die volgende syfers vir Njassaland in 1960):
245 gevalle gerapporteer; 188 persone skuldig bevind van intimidasie, en hy voeg daarly: „It must be remembered that only a fraction of the cases of intimidation are in fact reported." Hierdie praktyk is in ons eic land nie onbekend nie.

\section{Die huidige aksiepatroon van dir Pan- A/rikanisme.}

Organisatories vind die Pan-Afrikanisme in ons tyd sy beliggaming in politieke beweginge, vereniginge en partye in al die state en gebiede in openlike of bedekte vorm. Hulle gaan onder verskillende name soos, by ons, die A.N.C. en die P.A.C., in Suid-Rhodesië die National Democratic Party, in Noord-Rhodesië die U.N.I.P., en so meer, maar almal het - by alle verskille in skakering - in die grond van die saak dieselfde oogmerke, nl. die verwydering van blanke oppergesag en van alle vorme van rasse-differensiasie.

Daar is by die meeste van hulle 'n slerk begeerte na 'il Al-Afrikaanse samewerking (geïnspireer veral deur die stryd teen die ,kolonialisme") en daarom het daar in die jongste tyd veral oorkoepelende bewegings ontstaan soos:

\section{(a) Die Konferensie van Ona/hanklike. Afrikaanse State :}

Dit is 'n tweejaarlikse konferensie van die hoofde van alle onafhanklike $\Lambda$ frikastate met die uitsluiling van die Unie van Suid-Afrika. Deur dr. Nkrumah in 1958 in Accra gelanseer, beoog dit die verkry. ging van 'n gemeenskaplike buitelandse, ekonomiese en kulturele beleid. Tussen die sittinge van die konferensie tree die verteenwoordigers van die ledestate by die V.V.O. op as skakelkomitee. Hulle vorm 
die Afrikavleuel van die Afro-Asiatiese hlok.

(b) Die All-African Peoples Organisation:

'n Organisasie van nasionalistiese partye in die Afrika-state deur dr. Nkrumah byeengeroep in Accra in 1958, wat jaarliks vir 'n konferensie byeenkom. Die voorsitter is Tom Mboya wat, opvallend van die jaloesie tussen die state, die sekretariaat verskuif het van Accra na Lagos in Nigerië.

(c) Die Afro-Asiatiese Solidariteitsbeweging :

'n Organisasie van nasionalistiese partye (op nie-regeringsvlak) van Afrika en Asië (insluitende die Midde-Ooste), Rusland en Sjina, begin deur Abdul Nasser in Kairo in 1957. Sy program is min of meer dieselfde as die van die A.A.P.O. maar met 'n geringer aanhang in Afrika.

(d) Die beweging vir die Verenigde State van Wes-Afrika:

Hierdie idee is oorspronklik gepopulariseer deur Azikiwe van Nigerië en later oorgeneem deur dr. Nkrumah van Ghana. Dit geniet die algemene, indien ietwat vage, steun van die meeste politieke leiers in Wes-Afrika (met die uitsondering van die Rassemblement Démocratique Africain, waaroor meer later). Die doel is om alle gebiede vanaf Mauritania in die Noorde tot en met die Belgiese Kongo in 'n los politieke verband te bring. Die nucleus daarvan moet dan wees die Ghana-Guinee politieke samewerking. Hierdie gedagte is verbreed deur die Conakry-verklaring van Mei 1959 (Nkrumah en Sekou Touré) en die Saniquellie-Ooreenkoms (Julie 1959) tussen Ghana, Guinee en Liberië om 'n
Gemeenskap van Onafhanklike Afrika-State te vorm met behoud van die besondere regeringsinstellinge van elk en met behoud van vryheid van optrede in verband mel huitelandse verhoudinge. Die gedagte is in Desember 1960 'n stappie verder gevoer deur 'n ooreenkoms tussen Ghana, Guinee en Mali om 'n unie van die drie state te hewerkstellig en 'n gemeenskaplike ekonomiese en monetêre beleid te bevorder.

Dieselfde idee is beliggaam in ' $n$ aantal ander bewegings soos:

(e) Die Pan-Afrikaanse Beweging vir Oosen Stntraal-Afrika, wat begin is deur die Swart Nasionalistiese partye van Kenia, Tanganjika, Oeganda, Zanzibar en Njassaland in 1958. Die oogmerk is om volkome onafhanklikheid te verkry vir die Oos- en Sentraal-Afrikaanse gebiede op die grondslag van „één man, één stem." Dit staan simpatiek teenoor die gedagte van 'n uiteindelike federasie van Oos-Afrikaanse State. Die twee prominente leiers hier is Tom Mboya van Kenia en Julius Nyerere van Tanganjika.

(f) Die Rassemblement Démocratique Africain, sterk voorstanders van De Gaulle


Pan-Afrikanisme. Invloedryk in die Ivoorlius, Niger, Bo-Volta, Dahomey, Chad, Gabon en die (Frans) Kongo-Republiek. Leier: Houphout-Boigny van die Ivoorkus.

(g) Parti de la Féderation Ajricaine:

Dit is in 1959 in die lewe geroep hoofsaaklik deur wegbrekers uit die R.D.A. Dit staan vir volle onafhanklikheid en 'n federasie van alle Franse gebiede en vir samewerking met Frankryk. Die leiers daarvan was Leopold Senghor van Senegal en Modibo van Frans-Soedan. Hulle twee state 
is in 1959 as die Federasie van Mali vervang, maar het vanjaar weer uiteengespat. Ten slotte noem ek nog:

(h) Die All-African Federation of Trade Unions, wat nog maar in sy embrioniese. stadium is, maar wat probeer om alle Swart werkers in Afrika te organiseer in 'n beweging los van die internasionale arheidersliggame. Hulle is sterk Pan-Afrika. nisties gesind en voorstanders van politieke optrede deur werkers in belang van die verwerwing van onafhanklikheid.

Waar ons hier veral op moet let, is dat die Pan-Afrikanisme sy organe en kontakte dwarsdeur die Kontinent het ook by ons.

\section{Die implikasies van dis Pan-Afrikanisme vir ons :}

In die afgelope dekade, en veral in die laaste paar jare daarvan het die Pan-Afrikanisme, gesteun deur die liberalisme in die Weste en die koue oorlog tussen Weste en Ooste, sy onmiddellike doelstellings in groot dele van die Kontinent verwesenlik. In ander dele, soos in (Oos- en SentraalAfrika is helangrike suksesse behaal. Dat die Afrikanistiese leiers in ons land alles in hulle vermoë sal doen om die politieke en sosiale patroon wat in die Noorde vorm alangeneem het, ook hier te verwesenlik, en wel ongeveer met dieselfde metodes, meen ek, kan as eksiomaties aanvaar word. Hierin word hulle ook ondersteun en aangevuur deur dieselfde wêreldstrominge en magte wat elders in Afrika so werksaam was en is, en voorts deur die feit dat die Blankes verdeel en verward is deur die historiese en nou so noodlottige teenstelling tussen die Afrikaans- en Engelssprekendes.

In die toenemende ledetal van die Afrika-state in die V.V.O. verkry die Pan-Afrikanisme 'n steeds toenemende invloed op die terrein van die internasionale politiek, en hierdie invloed het ' $n$ trefkrag buite alle verhouding tot die mag van die betrokke state, as gevolg van die magswedywering tussen die V.S.A. en die U.S.S.R. Hierdie toestand word ernstiger na mate die Russiese en Sjinese penetrasie in Afrika vorder. Ek sluit af met 'n sitaat uit 'n baie insiggewende artikel in U.S. News and World Report van Francis B. Stevens, wat toestande in Suid-Afrika en die hele Afrika goed ken:

"The hig guns of Soviet propaganda. aided and abetted by the entire left wing (of the West?) are trained squarely on South Africa. The Soviet's objective is a black people's repuhlic in South Africa. Thus far there seems to be little understanding of this fact in the West."

Pretoria. $\quad$ A. J. H. van der Walt. 